movements with their pectoral and ventral fins, but hold them spread out. In the outspread fins there may occur very rapid vibrations.

The hinder part of the body remains somewhat lower than the fore part during flight.

Directly against the wind they commonly fly further than with the wind, or when their course and the direction of the wind form an angle together.

Most exocœeti which fly against the wind or with the wind continue during their whole course of flight in the direction in which they come out of the water. Winds coming laterally upon the original course of the exocœeti deflect these into their direction.

All exocoti which withdraw from ships fly during their whole course through the air, near the surface of the water.

When with strong winds they fly against the course of the waves, they commonly rise somewhat over each wave; some. times their tail dips slightly in the top of the wave.

Only those exocœeti whose air-course is crossed by a ship rise to considerable heights (at the most about five metres above the surface of the sea).

By day flying fish seldom light on the ship; they mostly do so at night, and never in calm, but only when the wind is blowing. They mostly fall upon ships which lie not higher than two to three metres above water, and when these are sailing on a wind (the wind coming obliquely from beyond) or with half a wind (the wind coming at right angles against the ship), and are sailing rapidly. Flying fish never come on board from the lee side, but always and only from the weather side.

Not uncommonly when their tail has dipped in the water they describe in the horizontal part of their course, a bow to the right or to the left side.

During wind and a rough sea they appear above the water more frequently than in calm weather.

Before ships, which come upon them in swimming, the exocœeti escape into the air, just as they do before fishes of prey and cetacea.

Many authors have affirmed, in explaining the flying of fish, that the pectoral fins operate like the wings of birds, bats, and of insects. Prof. Möbius, however, showrs that both the anatomical structures of the pectoral fins and their muscles, and the physiological relations of the position and size of the fins to the volume and weight of the whole body, are against flight-like movements of the pectoral fins.

The movements occasionally observed in these organs during flight are merely a vibration.

The true cause of these movements of fishes through the air are the spring-movements which they impart to their body by means of their very strong side muscles, just as other fish propel themselves powerfully through water. They spring out of the water with great velocity, because the air presents less resistance than the water, and when after some time, they fall back into the water, their outspread fins act like a parachute.

It is easy to understand how the action of the wind combines favourably or otherwise with their flight. By day the direction of their spring is so chosen that the disturbing ship is avoided. By night this orientation by the sense of sight is wanting, and the animals fall into the ship. As any air in strong motion, when it impinges against obstacles (a ship's side or waves), rises, it raises also the fish, so that this flies over the wave, or may come on board the ship. In short, as Prof. Möbius proves in detail, all the phenomena observed may be fully explained by the combined action of the oblique projection forwards and the wind. It may further be mentioned that the flying fish has a peculiar arrangement of the mouth, so that in this a portion of water may be carried during flight for the process of respiration.

\section{UNIVERSTTY AND EDUCATIONAL INTELLIGENCE}

THE Kingdom of Portugal has for its 4,700,000 inhabitants but a single university - that of Coimbra, which was originally founded at Lisbon in 1290 . The university has a corps of instructors numbering 70 , is attended by 1,100 students, possesses a library of 42,000 volumes, and is equipped with astronomical and meteorological observatories, as well as natural history collections. Advanced education is likewise provided for by polytechnics, medical academies, and industrial institutes in Lisbon and Oporto, and an agricultural school. The elementary schools of the land number 2,450 , and parents lose their political rights if their children cannot read and write at the age of 15 .

THE University of Strasburg is attended at present by the largest number of students recorded since its establishment, viz., 710 , consisting of 45 in theology, 195 in law, 150 in medicine; 177 in philosophy, and 143 in science.

THE new regulations for medical study in France require a term of four years, five examinations, including one in physics, chemistry, and natural history, practical work in the laboratories and anatomical theatre, and two years visiting of the hospitals. The sum requisite for this course of study is 1,360 francs -520 for lectures, and the remainder for examination fees, thesis, and diploma.

AN examination will begin at Merton College, Oxford, on Tuesday, October 15, for the purpose of electing to a Physica? Science Postmastership of the annual value of $80 l$, and tenable for five years from election. After two years of residence the College will raise, by a sum not exceeding $20 \%$. per annum, the postmasterships of such postmasters as shall be recommended by the tutors for their character, industry, and ability. Candidates, if members of the University, must not have exceeded six terms of University standing. Information may be obtained from the tutor in physical science.

Mr. SAMUEl Sharpe has promised to give 5,00ol. towards the building of the north wing of University College, London, so soon as the Council are prepared to begin the work. It is expected that this liberal donation, together with others which have been received, will enable the building to be very shortly commenced. A sum of $50,000 l$. in all will, however, be required to complete the extensions which are immediately contemplated.

\section{SOCIETIES AND ACADEMIES \\ LONDON}

Anthropological Institute, June 25.-Mr. John Evans, D.C.L., F.R.S., president, in the chair.-Dr. Paul Topinard, of Paris, was elected an Honorary Member, and the election of the following gentlemen as Ordinary Members was annotunced :The Rev. H. W. Watkins, Warden of St. Augustine's College, Canterbury; Hy. Wm. Jackson, M.R.C.S., F.R.A.S., F.G.S., of Lewisham, and Dr. Dunkley, of New Zealand.-A paper was read on the ethnology of the islands of the Pacific, by the Rev. S. J. Whitmee. This paper was chiefly intended to explain an ethnographic chart of the Pacific, coloured according to the author's own observations, and which, in the main, followed the divisions of races in previous charts. In speaking of the people, he said the Melanesians, or black race, might be regarded as the aboriginal people, and that they had affinities, more or less remote, with the blacks found in the various parts of the southern hemisphere. Probably these Melanesians once extended further across the Pacific than they now do. The brown MalayoPolynesian race had, doubtless, entered Polynesia from the west. The difficulties of such a migration were not insuperable. An example was given of a comparatively recent arrival of a vessel thought to be Chinese or Japanese, at Fotuna, or Home Island, containing forty people. There is a third people in Polynesia differing considerably from both of the others. These are the Micronesians. They probably are primarily from the Philippines, or some other portion of the Indian Archipelago, but are mixed with Melanesian and Malayo-Polynesian blood. There is also reason to believe they have had an admixture of Chinese or Japanese blood derived from the occupants of junks which have been driven by adverse winds to this region.--Mr. Worthington G. Smith read a paper descriptive of palæolithic implements from the gravels of N.E. London, and a paper was communicated by Mr. G. M. Atkinson on a new method of finding the cephalic index.

Entomological Society, July 3.-H. W. Bates, F.L.S., F.Z.S., president, in the chair.-Mr. Basil G. Nevinson was elected an Ordinary Member and Mr. John A. Finzi a Subscriber, $-M$. Pascoe exbibited a number of insects he had collected during a recent tour through Algeria and the south of Spain; with these there was a remarkable myriopod having the cylindri. cal body of the Julidx, but with only one pair of legs to each somite.-Mr. Boyd drew attention to the food plant of Eluchisto cerusella. This insect had always been considered to feed on the leaves of Arundo phragmites, which Mr. Boyd doubted, as he had lately found the larva feeding on Phalaris arundinaceon, 